\title{
Debating Future Harmonization of European Union VAT Regulations: Protests Among Swedish Nonprofit Organizations
}

Susanne Wallman Lundåsen

The self-archived postprint version of this journal article is available at Linköping University Institutional Repository (DiVA):

http:/ / urn.kb.se/ resolve?urn=urn:nbn:se:liu:diva- 156452

N.B.: When citing this work, cite the original publication.

Wallman Lundåsen, S., (2012), Debating Future Harmonization of European Union VAT Regulations: Protests Among Swedish Nonprofit Organizations, Nonprofit Policy Forum, 3(1), article 4, 1-14.

https:/ / doi.org/ 10.1515/ 2154-3348.1041

Original publication available at:

https:// doi.org/ 10.1515/2154-3348.1041

Copyright: De Gruyter Open

http:/ / degruyteropen.com/ 


\title{
Nonprofit Policy Forum
}

Volume 3, Issue 1

2012

Article 4

\section{Debating Future Harmonization of European Union VAT Regulations: Protests Among Swedish Nonprofit Organizations}

\author{
Susanne Wallman Lundasen, Ersta Sköndal University \\ College
}

\section{Recommended Citation:}

Wallman Lundasen, Susanne (2012) "Debating Future Harmonization of European Union VAT Regulations: Protests Among Swedish Nonprofit Organizations," Nonprofit Policy Forum: Vol. 3: Iss. 1, Article 4.

DOI: $10.1515 / 2154-3348.1041$

C2012 De Gruyter. All rights reserved. 


\title{
Debating Future Harmonization of European Union VAT Regulations: Protests Among Swedish Nonprofit Organizations
}

\author{
Susanne Wallman Lundasen
}

\begin{abstract}
The article discusses how the introduction of common European Union tax (VAT) regulations may affect the voluntary sector in Sweden. Historically nonprofit organizations in Sweden have enjoyed tax exemption given that their activities are considered to be of a common good purpose. The Commission of the European Union considers the tax exemption to be too generous in the case of Sweden and that it may distort competition in the free market. The protests are analyzed through a historical institutionalism framework where the Swedish paradigm for the voluntary sector is seen as deeply embedded in a specific institutional setting. The EU policy is interpreted by many nonprofit actors as threatening the existing institutional setting.
\end{abstract}

KEYWORDS: VAT, nonprofit organization, voluntary association, European Union, tax

Author Notes: I am greatful for the comments and suggestions by the anonymous reviewers. This research was supported by Riksbankens Jubileumsfond. 
Wallman Lundasen: Debating EU VAT Regulations

\section{Introduction}

The aim of this article is to investigate the debate about how prospective changes in common EU (hereafter EU) Value Added Tax (VAT) regulations might affect nonprofit organizations in Sweden from an institutionalism perspective.

The globalization of economies and changes in policies and regulations of international institutions, such as the EU, can have an impact, directly or indirectly, on both private enterprises and civil society organizations. The case of the EU can be considered a special case of globalization, as proper supranational institutions that have the capacity to create and, to some extent, enforce law upon its member states have been created. There is a growing body of literature discussing the Europeanization of the nonprofit sector in Europe (Kendall, 2010). Kendall (2010) has argued that, over the past few decades, the EU has shown increasing interest in policies related to civil society organizations. It has also been argued that the EU, particularly the Commission and the European Social Council, has used the concept of a "European civil society" as an instrument to gain support for policy proposals in the social area (Smismans, 2003: 21). In contrast, others have argued that there is a general lack of interest in furthering a European policy integration for civil society organizations in member states such as Sweden (Kendall and Fraisse, 2009; Olsson et al, 2009).

Previous studies have shown that civil society organizations in European countries seem to be very dependent on different historical legacies, legislation and welfare state arrangements. Several authors have argued for the importance of a historical and institutional context for understanding the case of Sweden (cf. Lundström and Svedberg, 2003; Salamon and Anheier, 1998; Hvenmark and Wijkström, 2004).

The general position of the Commission of the EU during recent decades has been to act in favor of a common and free economic market and to eliminate what are considered to be obstacles to free competition. If a member state does not comply with the directives of the EU, the Commission can initiate a case against that member state at the Court of the EU.

In what follows, a theoretical framework will be presented, followed by descriptions of the Swedish nonprofit organization, present tax regulations and the proposed changes. Thereafter, some of the core arguments against the Europeanization of the tax regulations that have been voiced by umbrella organizations of nonprofit organizations and political parties will be presented. Subsequently, an analysis of the arguments from the perspective of historical institutionalism is presented, and some broader conclusions are drawn. 


\section{Meta-Organizations and Standardization}

Ahrne and Brunsson (2005) develop the concept of meta-organizations, which are organizations that are composed of other organizations rather than individual members. The EU could be considered a meta-organization of states. The creation of these meta-organizations can create conflicts among competing members and the leaders of the meta-organizations (Ahrne and Brunsson, 2005:441).Within the EU, there are often competing interests between the member states that want to maintain national regulations and exceptions and the Commission or the Court of the EU that want to harmonize and standardize legislation across the EU to further integration. Standardization could be considered a means of conflict resolution within meta-organizations (Ahrne and Brunsson, 2005:442). Within the EU, processes of standardization are ongoing. The Green Paper written by the Commission on the harmonization of VAT regulations, which demands the minimization of differences in tax regulations within the EU, can be regarded as a process of standardization. The negotiation process between the state of Sweden and the Commission of the EU is ongoing. The case of the VAT directive can also be analyzed through the framework of historical institutionalism, which explains the persistence of values and how a prospected change in the VAT legislation directed from the EU is perceived by Swedish actors. The institutionalism perspective is used to interpret why certain arguments are brought forward. ${ }^{1}$

\section{The Impact of Institutions on Civil Society Organizations}

The term "institutionalism" is a broad theoretical concept that has been defined in myriad ways (cf. Peters, 2010). In the present article, an institution is defined as norms, values, regulations and routines (Peters, 2010, Chapter 4; cf. Peters, Pierre and King, 2005; Brunsson, 1990). What has often been denoted as historical institutionalism focuses on how policies from the past have an enduring influence on future policy decisions (Steinmo, Thelen and Longstreth, 1992; Skocpol, 1992; Peters, Pierre and King, 2005). To understand present policy, it is important to understand the legacy of the past (cf. Peters, 2010). Under this theoretical framework, in addition to the path dependency from historical decisions, institutions are dominated by ideas (mainly from elites) and their influence on decisions (Peters, Pierre and King, 2005). Change can occur at critical junctures, and a great deal of political pressure favoring change is required (Peters, 2010, Chapter 4). Otherwise, policy is described as being in a state of equilibrium,

\footnotetext{
${ }^{1}$ It would be possible to understand the opposition from the Swedish nonprofit organizations using a purely rational logic; they prefer not to potentially complicate their administration. However the point here is to understand why certain arguments are brought forward and why there seemingly is a unanimous political support for the position opposing the legislation.
} 
where changes that threaten the equilibrium are opposed and/or balanced (Peters, 2010). The theoretical core has been criticized for not capturing the small changes that occur in daily policy processes and for not dealing with the agency (Peters, Pierre and King, 2005). However, historical institutionalism is useful in interpreting opposition to change (Peters, Pierre and King, 2005).

In the scholarly debate on civil society, much consideration has been given to the importance of regulations in the shaping of civil society organizations (Olsson et al, 2009). Studies have found that institutional differences affect the types of organizations that emerge and the relationship between the organizations and the state (Schofer and Fourcade-Gourinchas, 2001; Salamon and Anheier, 1998). Salamon and Anheier (1998) argue for the social and historical origins of civil society, which can be interpreted as an institutional explanation. Salamon and Anheier classify states on the basis of two different dimensions: the scale of the nonprofit sector (small or large) and government social welfare spending. Salamon and Anheier have identified four ideal types of regimes governing the voluntary sector: statist, liberal, social democratic and corporatist. In a social democratic regime, such as Sweden, high spending on social welfare has discouraged a large nonprofit social service and encouraged advocacy groups and organizations that focus on culture, recreation and sports (cf. Salamon and Anheier, 1998).

Schofer and Fourcade-Gourinchas (2001:810) argue that institutions shape individual behavior through "cultural frames." The concepts adopted by Schofer and Fourcade-Gourinchas (2001: 810-815) to explain individual variation in associational involvement are statism and corporateness. Statism refers to the degree of centralization of the state's power, completely independent of organizations; at the other end of the scale, political power is transferred to the "organized society" (Schofer and Fourcade-Gourinchas, 2001: 811). Corporateness describes whether citizens tend to represent themselves individually in the political sphere or are empowered only in their capacity as members of larger groups (Schofer and Fourcade-Gourinchas, 2001: 813). Sweden (along with the other Scandinavian countries) is characterized by low a level of statism and high level of corporateness. This combination leads to comparatively high levels of involvement, especially in older types of social movement (Schofer and Fourcade-Gourinchas, 2001).

There is a long tradition of research focused on tracing the historical roots of the civil society in Sweden. These roots have been found to date much further back than the origin of the social democratic welfare state (Jansson, 1985; Lundkvist, 1974; Larsson, 2008). However, the subsequent legislative changes and implementation of policies during the $20^{\text {th }}$ century, with a long period of social democratic dominance, have contributed to framing the institutional setting of the Swedish civil society organizations. This institutional setting has had a 
lasting impact (Schofer and Fourcade-Gourinchas, 2001; Olsson et al 2009; Trägårdh, 2010b).

The Swedish political system has been described as an input democracy with the focus on the input side of the political process (Goodin, 2004). The political system is relatively open on the input side for civil society organizations to propose policy changes and bring forward their demands. Historically, there has often been a focus on balancing the interests of different groups and striving toward consensus (Goodin, 2004). The procedure of remiss, when legislators let organized interests take part in and express their opinions on proposed legislation, ${ }^{2}$ has institutionalized the relationship between the state and civil society organizations (Trägårdh, 2007; Olsson et al, 2009). The institutional setting also shows how the state and organizations have intertwined relationships that reflect what has been characterized as a special Swedish social contract (Trägårdh, 2010a).

Trägårdh (2010b) also argues for the importance of tax legislation in shaping the type of civil society organizations that emerge and shows how tax regulations may become critical in defining the landscape of civil society organizations. According to Trägårdh (2010b), while the United States has more charities than advocacy groups because of its favorable tax legislation with regard to charities, other countries such as Sweden have a larger number of advocacy groups as a result of policies based on direct state support for civil society organizations.

\section{Nonprofit Organizations in Sweden}

Within the sphere of civil society organizations is the category of nonprofit organizations $^{3}$ (ideella föreningar), which have come under scrutiny in response to the proposed changes of the VAT regulations. Swedish nonprofit organizations are essentially member-based organizations. There are no legal definitions in Sweden of what constitutes a nonprofit organization, although several propositions have indicated the need for legislation regulating nonprofit organizations. Today, our understanding of nonprofit organizations is based upon praxis and how taxation law defines nonprofit organizations, distinguishing those with a "common good purpose" (i.e., acting in the interests of the general public) from those with economic interests.

\footnotetext{
${ }^{2}$ The legislator is free to decide to what extent it wishes to regard or disregard the opinions that are expressed. Disregarding these opinions completely may come at a political cost by turning interest groups and possibly public opinion (hence the electorate) against them.

${ }^{3}$ The term 'nonprofit organization' is narrower than 'civil society organization' as it indicates a specific type of organization. There is no perfect translation of the term ideell förening, but within an international and legal context this is the most commonly used term (cf. Powell and Steinberg, 2006).
} 
It has been extensively argued that the Swedish civil society organizations are dominated by a popular movement paradigm (folkrörelse) (Hvenmark and Wijkström, 2004; Olsson et al., 2009). Under this institutional framework, organizations are supposed to be democratically governed by their members, as indicated in the tax regulations cited above, and the economic resources and number of employees are small, making most of the organizations very dependent upon the voluntary efforts of their members (Olsson et al., 2009).

The type of nonprofit organization that engages the most volunteers is the sports association. Surveys on volunteering have shown that approximately $20 \%$ of the population is involved with a sports club or an association engaged in outdoor activities (Svedberg, von Essen and Jegermalm, 2010). Sports organizations are composed of a large part of the youth population. Studies have also shown that between 80 and $75 \%$ of the Swedish adult population has at least one membership in an association (Hvenmark, 2008; Statistics Sweden, 2011). Although it is difficult to obtain exact estimates of the levels of citizen involvement in nonprofit organizations, many studies indicate that the Swedish population is involved in associations to a comparatively high degree (Svedberg, von Essen and Jegermalm, 2010; Lundström and Svedberg, 2003; Schofer and Fourcade-Gourinchas, 2001).

\section{Present Swedish VAT Regulations}

The Swedish tax system is based upon different sources. The main source of taxation is the progressive income tax. In addition to income taxes, organizations pay value added taxes on certain services and commodities that they sell. The percentages of VAT to be paid by the organizations to the state vary both between types of organizations and types of activities/commodities and to whom a commodity/service is sold. The regulations surrounding which VAT rate to pay and under what circumstances are quite detailed and are often considered an obstacle by organizations such as the Confederation of Swedish Enterprise. ${ }^{4}$

The present Swedish VAT regulations distinguish between nonprofit organizations and nonprofit organizations with a "common good purpose." The definition of a common good purpose follows an old piece of legislation: it is a purpose that encourages the defense of Sweden; encourages the care and upbringing of children; contributes to education or teaching; acts in the interests of the needy; encourages research at universities or other similar institutions; encourages cooperation among the Nordic countries; and encourages religious, charitable, social, political, artistic, sports or other cultural purposes (Swedish tax agency, 2011). Tax law grants nonprofit organizations a public-purpose tax

\footnotetext{
${ }^{4}$ A search on the webpage by the Swedish Confederation of Enterprise on the term VAT (moms) yields over 900 hits, most which voice negative opinions.
} 
exemption if they comply with four conditions: the main aim of the activity must be one of public interest; the activities organized must be in the public interest; the association must, with certain restrictions (e.g., age, disabilities, temperance), in principle, be open to anyone who wishes to become a member; and the vast majority of funds that flow into the nonprofit organization must be used to benefit the general public. The definition of a common good purpose and benefit to the general public is ultimately a normative decision by the legislator.

Nonprofit organizations with a common good purpose do not have to account for VAT on revenues from sales, sponsorships or other events that are organized to finance the activities of the associations. The tax exemption is extended to activities that have a "natural connection to the purpose of the nonprofit organization," such as sports associations' ticket sales for sports events and activities that aim to improve the experience of the participants, such as serving coffee or hot dogs at meetings. However, there are limitations; at least $90-95 \%$ of the activities of the nonprofit organization must be dedicated to purposes of common good, and at least $80 \%$ of the income of the nonprofit organization must be used for purposes of common good over a period of five years (Swedish tax agency, 2011). About 25\% of all the registered nonprofit organizations pay VAT, as they have a turnover above approximately 37,000 US Dollars (DS 2009:58).

\section{VAT Regulations and the Proposed Changes by the European Union}

Sweden adopted several changes to its tax regulations before becoming a member of the EU in 1995. In 1994, the Swedish tax regulations were changed in accordance with the EU regulations (DS 2009:58). The EU regulations concerning VAT were primarily found in the directive 2006/112/EG (DS 2009:58). "This directive used the term "taxable person," while Swedish law adopted the slightly different concept of "professional occupation." In 1999, a governmental inquiry was initiated to investigate whether differences existed between the Swedish national taxation laws and the intentions of the EU. In 2002, a change in the Swedish regulations was proposed by the inquiry, namely, the adoption of the term "taxable person." The inquiry also made suggestions as to how to maintain the tax exemptions for nonprofit organizations and registered religious faith congregations (DS 2009:28; SOU 2002:74).

The Commission of the EU did not, however, accept the Swedish interpretation of the tax regulations and did not approve the tax exemptions for nonprofit organizations and registered religious faith congregations on the basis of the argument that they do not act on a professional basis. Therefore, in 2008, the

\footnotetext{
${ }^{5}$ A directive is legislation that is applicable within the EU member states; the EU member states have agreed to comply with EU regulations through their membership in the EU.
} 
Commission of the EU initiated a case in the EU Court against the state of Sweden for not adhering to the EU regulations. The Commission argued that the Swedish tax regulations included an overly broad tax exemption for nonprofit organizations; furthermore, the Commission asserted that the Swedish term "professional occupation" did not correspond to the term "taxable person" and did not adhere to EU regulations (DS 2009:58). The Swedish government initiated an inquiry by legal experts to investigate whether any substantial differences existed between the Swedish tax regulations and the EU regulations. The governmental inquiry DS 2009:58 concluded that some changes to the present Swedish regulations were necessary and proposed the introduction of new exemptions for the voluntary sector that aligned with existing EU regulations.

DS 2009:58 made some attempts to simulate the potential effects of the changes to nonprofit organizations. However, one of the main conclusions was that it was difficult to predict the changes and costs involved, mainly because of the general lack of reliable statistics regarding the voluntary sector, but also because the nonprofit organizations themselves varied in terms of size and degree of professionalization. The inquiry also concluded that it would be difficult to pinpoint which activities would continue to be ineligible for VAT and which activities would be considered taxable (DS 2009:58:240). The inquiry also suggested that the government, under certain circumstances, ought to compensate nonprofit organizations if their costs would drastically increase as a result of the changes to the VAT regulations.

The Green Paper from the Commission of the EU states a general desire to overlook existing exemptions from VAT. The Commission argues that it is advisable to enlarge the base for collecting VAT rather than raise the VAT level; therefore, exemptions from VAT should be reduced to simplify and align EU regulations concerning VAT. National decisions to grant certain actors tax exemptions could be considered to grant favors and, therefore, distort the free market. The position of the Commission is that the Swedish exemption for nonprofit organizations is too broad and goes against the EU VAT directive. The Swedish tax exemption must, according to the position of the Commission, be extended to small enterprises as well, rather than solely directed at nonprofit organizations.

\section{Protests Against Europeanization of VAT Regulations}

There have been many protests by nonprofit organizations against changes in the VAT regulations. There is no single umbrella organization that can speak on behalf of all the nonprofit organizations in Sweden. Several large umbrella 
organizations have expressed their opinions; they have advanced three main arguments. ${ }^{6}$

The first argument against the introduction of mandatory VAT has been that it would increase costs for Sweden's nonprofit organizations in terms of both time spent declaring taxes and time following what are considered to be complicated VAT regulations. It is not clear, when studying the proposal from the governmental inquiry (DS 2009:58), when VAT is applicable and when activities are exempt. For example, if a nonprofit organization arranged a dance event to raise money, the activity could be considered both entrepreneurial (in which case the association would be required to pay VAT) and beneficial to the public health (in which case the association would be exempt).

A second argument is that voluntary organizations would also require professional staff who could interpret when to apply VAT. Professionalization, however, is thought to be against the inherent values of many nonprofit organizations. A third argument is that it is difficult to foresee whether introducing new rules would make it more costly for the nonprofit organizations. The influential Swedish Association of Local Authorities and Regions supports a continuation of the present exemptions. The large labor market organizations, such as the Trade Union (LO) and Confederation of Swedish Enterprise, have expressed somewhat different opinions. LO has argued that the general exemption is too costly, and the Confederation of Swedish Enterprise has supported the exemption, if small enterprises are treated equally.

Among the political parties, opposition to the changes in tax regulations has been more or less unanimous. Many arguments similar to those used by the umbrella organizations of different nonprofit organizations have also been used by representatives of political parties.

Within the government, all parties have voiced opposition. The Center Party's (Centern) former representative in the European Parliament, Lena Ek, has written to the Commission of the EU:

To say that the present Swedish regulations should be considered as distorting the competition is unreasonable and an unrealistic way of reasoning. The sale of cookies and hot dogs at a soccer ground during a soccer game does not compete with cafés or fast-food businesses. Instead, this income contributes to nonprofit organizations, giving them the ability to operate under reasonable economic conditions. (http://www.lenaek.se/?s=moms, 2011-07-26, my translation).

${ }^{6}$ The arguments are based upon opinions expressed by National Sports Confederation (RF), National Pensioners' Organization (PRO), CIVOS (umbrella organization for civil society organizations), Forum for voluntary social work, FRII (fundraising umbrella organization), Swedish Hunters' Organization 
The left-wing political parties have also protested in unison. In a letter to the Swedish minister of finance, Gunnar Sandberg, the Social Democratic Party's representative in parliament, wrote:

If nonprofit organizations had to start accounting for VAT, then they would have both increased costs and greatly increased administrative work. Their ability to finance their own activities would be severely diminished because the volunteer treasurer would have more responsibilities and a heavier workload. If the Commission of the EU were to achieve its aim, it would become more expensive for our children to take part in sports, which would lead to social divisions within society. (http://www.riksdagen.se/webbnav/index.aspx?nid=67\&dok_id=GY11453 , 2011-07-26, my translation).

The position of the majority party in the government coalition (the Moderate Party) has been that total exemption is not feasible; instead, they have aimed to create a ceiling for the turnover of nonprofit organizations. Associations above the ceiling would be obliged to pay VAT. The ceiling would include the largest sports clubs and other organizations that must adhere to the VAT regulations. The main argument for creating a ceiling is that nonprofit organizations with a turnover above the ceiling resemble private companies more than they resemble nonprofit organizations, and they should therefore adhere to the regulations that govern private enterprises. The proposed ceiling has been set at a figure corresponding to approximately 150,000 USD.

In June 2011, the tax committee of the Swedish parliament met the responsible commissioner of the EU, Semeta, to discuss the issue of VAT exemption for Swedish nonprofit organizations. In October 2011, the European Parliament expressed its support for the Swedish position to continue to grant nonprofit organizations tax exemption. However, in December 2011, the Commission reaffirmed its position not to grant any exemption. It remains to be seen how the issue will develop.

\section{Resistance or Change?}

Some of the arguments brought forward in the debate against changes in the Swedish exemptions in the tax law for nonprofit organizations are presented above. The character of Swedish civil society has been shaped over a long period by policies, practices and regulations (Olsson et al, 2009; Trägårdh and Rothstein, 2007; Trägårdh, 2010a). In the past, Swedish civil society organizations have opposed any intervention that could be considered to undermine national embedded traditions (Kendall and Fraisse, 2009: 214). 
From the historical institutionalism, we can draw the conclusion that it is difficult to realize change and that patterns of path dependency influence the course of events (cf. Peters, 2010). Sweden has previously been thought to have associations that are deeply embedded within the institutional setting and reluctant to change (Olsson et al 2009; Hvenmark and Wijkström, 2004; cf. Amnå, 2006). Reluctance to change and path dependencies could be understood from a historical institutionalist perspective (Steinmo, Thelen and Longstreth, 1992; cf. Peters, Pierre and King, 2005). The dominating idea for the Swedish civil society organizations has been the ideal of fostering popular movements, governed by democratic ideals and mainly run by volunteers in their spare time (Hvenmark and Wijkström, 2004; Lundström and Svedberg, 2003; Olsson et al, 2009). The arguments brought forward by political representatives and the nonprofit organizations embody the ideas of the norms of the popular movement paradigm.

The processes of resistance against the proposed changes in tax regulations could be considered to go against the ideas that have long influenced the image of Swedish voluntary organizations. The arguments put forth in the debate, such as the increased need for technical skills among volunteers, could lead to a real change in the institutional setting and are thus perceived to influence the character of Swedish nonprofit organizations, changing them from being run by laymen and amateurs to becoming more professional. The feared increased cost, in time and money, would also counter the idea that nonprofit organizations have small economic resources and rely upon voluntary efforts. It is important to note that these characteristics describe ideal types of Swedish nonprofit organizations. $^{7}$

Processes of resistance toward Europeanization have also occurred on previous occasions (Kendall and Fraisse, 2009). At present, the mechanisms of resistance seem to be stronger than the processes of change.

The example of the EU VAT directive is instructive in many different ways. First, it shows how policy changes from international institutions may affect the national institutional context by changing practices that have a long history, such as the tax exemption for certain nonprofit organizations. Second, it shows how international institutions, such as the Commission of the EU with its clear focus on facilitating the common market, may ignore the role played by national nonprofit organizations.

\section{Conclusions}

Several studies show how institutions shape civil society, both in terms of organizations that emerge and the propensity of citizens to volunteer (Schofer and

\footnotetext{
${ }^{7}$ Confront (Hvenmark, 2008).
} 
Fourcade-Gourinchas, 2001; Goss, 2010). Sweden has had a history of defending the status quo in the legislation and practices connected to civil society organizations (Kendall and Fraisse, 2009; Olsson et al, 2009).

The present study investigates how the proposed Europeanization of VAT regulations has been received by the voluntary sector in Sweden. Umbrella organizations have encouraged Swedish nonprofit organizations to protest the Europeanization of the VAT regulations. As previous studies have shown, civil society organizations are deeply embedded within national institutional and historical contexts (Salamon and Anheier, 1998; Schofer and FourcadeGourinchas, 2001; Olsson et al, 2009; Smismans, 2003; Trägårdh, 2010). Moreover, partly because of the peculiar institutional setting of Sweden, which places voluntary organizations in the middle of the policy formation process through the system of remiss, it has not been difficult to find internal political support for protests against the Europeanization of VAT regulations. As Peters, Pierre and King (2005) have shown, there is a need to accept new ideas that promote policy change among key actors in order to achieve change. In the case of Sweden, the proposed legislative change is perceived to challenge one of the core values of civil society organizations, namely, that they are run by laymen volunteers.

However, institutional frames, such as regulations of taxation, may be of paramount importance for the voluntary sector. It has been suggested that it is difficult to predict how the proposed changes in VAT regulations would actually affect the Swedish nonprofit organizations if they were implemented (DS 2009:58). A possible development is that the nonprofit organizations create local umbrella organizations that provide administrative support, as has been suggested by the National Sports Confederation. The biggest fear of the nonprofit organizations is that these changes will have a radical impact on small organizations and in extreme cases the changes would make it impossible to continue to exist as a nonprofit organization. The loss of a large number of nonprofit organizations would probably have a profound impact on society and especially in smaller communities where nonprofit organizations play an important part of the social life. The present case is an example of how European integration and the creation of a common European market could affect the voluntary sector. The example also shows how distinct the traditions within the voluntary sector are within the EU and how difficult it is, from the institutional EU level, to impose change. Swedish nonprofit organizations, along with Swedish politicians, have argued that the EU has a general lack of knowledge of the Swedish situation. The EU has a history of first introducing changes within the economic sphere, relating to principles of free trade, that subsequently have driven changes in policy. The introduction of common VAT regulations could be considered a way of introducing changes that may affect organizations in a 
standardizing direction. In contrast with the voluntary compliance among organizations to which the literature on standardization usually refers, the EU can also enforce standardization through changes in regulations.

This case also shows that, even though there seems to be a national agreement about the core values of nonprofit organizations, these values may be challenged by an international institution such as the EU. The desire of the Commission of the EU to protect the free European market and eliminate national obstacles to a common European market may also involve the voluntary sector.

\section{References}

Ahrne, G. and Brunsson, N. (2005) Organizations and meta-organizations. Scandinavian Journal of Management. (21), 429-449.

Amnå, E. (2006). Still a Trustworhty Ally?: Civil Society and Transformation of Scandinavian Democracy. Journal of Civil Society, 2(1), 1-20.

Brunsson, N. (1990). Reformer som rutin. In Brunsson, N and Olsen, J (eds.) Makten att reformera. Stockholm: Carlsson Bokförlag.

Commission of the EU (2010). Green Paper: On the future of VAT

Towards a simpler, more robust and efficient VAT system. Brussels: Report 1455 final.

DS 2009:58. Mervärdesskatt för den ideella sektorn, m.m. Stockholm: Ministry of Finance.

Goodin, R. (2004). Input Democracy. In Engelstad, F and Østerrud, Ø. (ed), Power \& Democracy. Aldershot: Ashgate.

Goss, K. (2010). Civil Society and Civic Engagement: Towards a Multi-Level Theory of Policy Feedbacks. Journal of Civil Society. 6(2), 119-143.

Hvenmark, J. (2008). Reconsidering Membership: A Study of Individual Members' Formal Affiliation with Democratically Governed Federations. Stockholm: Stockholm School of Economics. Dissertation.

Hvenmark, J. and Wijkström, F. (2004). The Popular Movement Marinade: The dominant civil society framework in Sweden. Paper presented at the $6^{\text {th }}$ ISTR International Conference, Toronto: Canada.

Jansson, T. (1985). Adertonhundratalets associationer: forskning och problem kring ett sprängfullt tomrum eller sammanslutningsprinciper och föreningsformer mellan två samhällsformationer c:a 1800-1870. Uppsala: Studia historica Upsaliensia, Uppsala universitet.

Kendall, J. (2010). The Limits and Possibilities of Third Sector Europeanization. Journal of Civil Society. 6 (1). 39-65. 
Wallman Lundasen: Debating EU VAT Regulations

Kendall, J. and Fraisse, L. (2009). The European Statute of Association: Why Still an Obscure but Contested Symbol in a Sea of Indifference and Scepticism?. In Kendall, J. (ed.) Handbook on Third Sector Policy in Europe. Cheltenham: Edward Elgar.

Larsson, J. (2008). Folkhemmet och det europeiska huset: svensk välfärdsstat $i$ omvandling. Stockholm: Hjalmarsson \& Högberg.

Lundkvist, S. (1974). Politik, nykterhet och reformer : en studie i folkrörelsernas politiska verksamhet 1900-1920. Uppsala: Studia historica Upsaliensia 53, Uppsala universitet.

Lundström, T. and Svedberg, L. (2003). The Voluntary Sector in a Social Democratic Welfare State - The Case of Sweden. Journal of Social Policy. 32(2), 217-238.

Olsson, L-E., Nordfeldt, M., Larsson, O. and Kendall, J. (2009). Sweden: When strong third sector historical roots meets EU policy processes. In Kendall, J (ed.) Handbook on Third Sector Policy in Europe. Cheltenham: Edward Elgar.

Peters, G.B. (2010). Institutional Theory in Political Science: The New Institutionalism. London and New York: Continuum.

Peters, G.B.., Pierre, J. and King, D.S. (2005). The Politics of Path Dependency: Political Conflict in Historical Institutionalism. Journal of Politics. 67(4), 1275-1300.

Powell, W. and Steinberg, R. (2006). The Nonprofit Sector: A Research Handbook. New Haven: Yale University Press.

Salamon, L. and Anheier, H. (1998). Social Origins of Civil Society: Explaining the Nonprofit Sector Cross-Nationally. Voluntas. 9 (3), 213-248.

Schofer, E. and Fourcade-Gourinchas, M. (2001). The Structural Contexts of Civic Engagement: Nonprofit organization Membership in Comparative Perspective. American Sociological Review, 66(6), 806-828.

Skocpol, T. (1992). Protecting Soldiers and Mothers. The Origins of Social Policy in the United States. Cambrige, MA: Harvard University Press.

Smismans, S. (2003). European Civil Society: Shaped by Discourses and Institutional Interests. European Law Journal, 9 (4), 482-504.

SOU 2002:74. Mervärdesskatt i ett EG-rättsligt perspektiv. Stockholm: Ministry of Finance.

Statistics Sweden (2011). Medborgerliga aktiviteter 2008-2009. Stockholm: Statistics Sweden. Report 120.

Steinmo, S., Thelen K., and Longstreth, F.(eds.) (1992). Structuring Politics: Historical Institutionalism in Comparative Perspective. Cambridge: Cambridge University Press. 
Svedberg, L., von Essen, J. and Jegermalm, M. (2010). Svenskarnas ideella engagemang är större än någonsin: Insatser $\mathrm{i}$ och utanför föreningslivet. Stockholm: Enheten för forskning om det civila samhället, Ersta Sköndal Högskola, Report to the Government of Sweden.

Swedish tax agency. (2011). Skatteregler för ideella föreningar och stiftelser. Stockholm: Skatteverket.

Trägårdh, L. (2007) The Governance and the Creation of Social Capital in Sweden. In Trägårdh, L. (ed.) State and Civil Society in Northern Europe. New York: Berghahn Books.

Trägårdh, L. (2010a). Rethinking the Nordic welfare state through a neo-Hegelian theory of state and civil society. Journal of Political Ideologies. 15(3), 227239.

Trägårdh, L. (2010b). Incentives and Conditions Shaping Civil Society. Journal of Civil Society. 6(2), 185-187.

Trägårdh, L. and Rothstein, B. (2007) The State and Civil Society in an Historical Perspective: The Swedish Case. In Trägårdh, L. (ed.) State and Civil Society in Northern Europe. New York: Berghahn Books. 